\title{
USING PAST EXPERIENCES TO DEVELOP AN EARLY WARNING SYSTEM FOR THAILAND'S PROPERTY MARKET
}

\author{
PIRIYA PHOLPHIRUL \\ National Institute of Development Administration, Thailand
}

\section{ABSTRACT}

This paper has a two-fold purpose. First, it analyzes the causes, effects and consequences of speculative bubbles, and Thailand's past real estate crises. The role of excessive credit extended by financial institutions is discussed as the main cause of real estate bubbles. Excessive credit is also believed to have been the major cause of passthrough financial imbalances and economic instability. Second, an early warning system for predicting a property-market crisis is created using two approaches: signal analysis and probability analysis. It shows that there are two leading indicators; the "ratio of post-finance to bank loans" and the "percentage increases in the price of construction materials", that currently exceed the threshold level are signaling a future real estate crisis. However, the interest rate, which the models reveal as the most significant indicator of a crisis, is still far below the threshold level. Moreover, many financial institutions are currently offering competitive incentives for fixed-rate loans of, say, 1-3 years, to buyers of houses. For all these reasons, the probability of a real estate crisis in Thailand is quite low for the next 1-2 years, i.e., 2005-2007. However, neither model treats the potential impact of other incidents, such as restructuring of the financial system, proper bank monitoring and new urban planning, all of which could change the overall structure of the economy.

Keywords: Real Estate Bubbles, Real Estate Crisis, Early Warning System

\section{INTRODUCTION}

Financial crises always lead to tremendous shocks and adverse effects wherever they occur. The major causes of this type of crisis are regularly investigated. Such inquiries reveal variations in market structure, timing and degree of vulnerability to the crises. In the case of Thailand, this investigation shows the conditions under which the real estate sector became a major source of vulnerability in a rapidly growing economy during the boom decade: 1986-1996. It then proceeds to show how the fundamentals of rapid economic growth originally started a genuine real estate boom that eventually turned into 
a costly bubble. In addition, a number of other studies have explained how a rapidly growing economy can cause inefficiency and distortion in the market when improper regulatory measures are in place that leads indefinitely to a high degree of speculation in asset markets. The aftermath of this bubble played a major role in the domestic banking crisis. In other words, the costly financial crisis in Thailand comprised at least three different crises: a real estate crisis, a banking crisis, and finally a currency crisis (see Renaud, 2000).

In addition to Thailand's access to global capital markets at the time, outdated banking practices also played a major role in the real estate crisis. First, bank lending to this sector fueled the boom; then regulatory mechanisms tended to accentuate downturns. The greatest proportion of credit extended by financial institutions was from commercial banks, which accounted for more than 75 percent of the total credit provided by financial institutions. Because the banking practices followed in Thailand during the boom were based on laws concerning banking and secured lending dating back to the 1920s and 1930s (without having been updated), most lending was done on a collateral basis, i.e., with physical property serving as collateral. The financial liberalization that took place at the beginning of the 1990s resulted in excessive credit being extended to the real estate sector as did the Bangkok International Banking Facilities (BIBF) process, which obtained foreign currencies for domestic borrowing. Huge capital flows in the form of excess lending to this sector inflated property values. When a decline in property values started because of market imbalances, there were negative effects on financial positions and loan loss provisions covered by banks and finance companies. Thailand's financial institutions thereafter faced greater provisioning requirements against non-performing loans (NPLs), which led to a serious credit crunch.

Corsetti, Pesanti, and Roubini (1998) evaluated the impact of the real estate crisis on the banking sector and made a comparison among ASEAN banks. These studies showed that, 30-40 percent of the banks' total assets were adversely affected by property exposure and approximately 80-95 percent of the collateral put forward when attempting to obtain banking credit generally comprised physical real estate, such as land, houses or factories. Therefore, there is no question why the sharp drop in property prices had a direct impact on lowering the valuation of the banks' assets. Firms facing credit constraints also had to survive; they were forced to sell their collateral to fulfill margin requirements. ${ }^{1}$

In view of the past, some people fear that real estate bubbles may occur again in the future. Policy makers, academics and business persons want to know how to prevent real estate crises from occurring again. A number of effective leading indicators, including an

${ }^{1}$ For more information about "margin requirements", see Edison, Luangaram, and Miller (2000) and Luangaram and Miller (2004). 
early warning system for preventing this type of crisis, should be a matter of concern. However, the development of such a system has not received much attention because of the lack of data. Nevertheless, market analysts, academics, including many private researchers, still rely on some standardized leading indicators as the major tool for predicting bubbles and crises in the property market. From an academic and statistical viewpoint, relying only on leading indicators may result in less ability to make predictions; thus, adopting appropriate indicators has made it even more difficult for market analysts and researchers to proceed. Therefore, this paper is aimed at developing an early warning system for anticipating real estate bubbles and crises in Thailand. The ability of such a system to signal future events should be of benefit to many developers, house buyers and policy makers, enabling them to be aware of and able to manage some risks and vulnerability that might occur in the future.

Section II analyzes the causes, effects and consequences of a real estate crisis for Thailand's property market. The role of excessive credit supplied by financial institutions will be discussed as the main cause of speculative patterns in the past with regard to Thailand's property market. It will also analyze how the adverse effects in this sector passed through financial imbalances and economic instability afterwards. Section III develops the early warning system for the real estate market to determine whether or not speculative bubbles currently exist in this sector; it adopts two approaches; namely, signal analysis and probability analysis to compare the results. Section IV concludes the paper pointing out some weaknesses in adopting the model.

\section{REAL ESTATE CRISIS IN THAILAND}

The rapid growth of the economy during the period 1986-1996 paralleled the emergence of the real estate industry in Thailand. However, it remained an immature industry, lacking depth, proper monitoring, and a modern regulatory and financial infrastructure. The emergence of this new sector was obvious in Bangkok with a wide range of facilities being available, ranging from traditional housing to condominium apartments; from the upper floors of shop-houses to modern office buildings; and from street markets to shopping centers. Many of these real estate assets are heavily concentrated in the Bangkok Metropolitan Area, which dominates the Thai economy. Renaud (2000) explained the importance of the real estate sector to the Thai economy. He investigated the value of the total stock of real estate in greater Bangkok, finding that it amounted to about 2,200 billion baht at the end of 1997, following a severe financial crisis (at that time, the value of the Baht currency ranged from 38 to 55 baht per US dollar). However, approximately one quarter of the value was non-residential real estate, especially office and retail space. The value of Bangkok's stock in real estate was greater than its gross provincial product in 1997, which was equivalent to 45 percent of the national GDP. 


\section{The real estate market before the crisis}

The boom in residential property led to the rapid modernization of Bangkok's housing stock. New housing units were built not only for the city's rapidly increasing population, but also for households upgrading their housing facilities. One fundamental change in the housing sector during the boom period was the emergence and rapid growth of professional housing developers. Prior to 1984 , house construction was driven mostly by individual owner-builders. The share of developer-built housing was only 12 percent in 1984, but it increased to 83 percent in 1996, i.e., from about 30,000 units in 1974 to the peak of 172,419 units in 1995. The Gulf War and the domestic political turmoil of 1991 resulted in a temporary drop in the number of housing units constructed annually to fewer than 110,000 units in 1992. Housing started to boom again in 1994 until it peaked in 1995, which implied excess supply in the housing sector. The Government Housing Bank estimated that about 300,000 residential units in greater Bangkok were unoccupied. This vacant stock was equivalent to two years of housing supply in the market.

Despite the large stock of vacant housing units, developers still kept building more houses, because there are some adjustment lags in this sector in terms of demand and supply. On the supply side, developers usually spend at least six months in building a house; on the demand side, house buyers must take some time to make their decision to purchase a house. Nonetheless, the number of units built started to drop significantly, from 145,355 units in 1997 to 63,864 units in 1998, and then to 33,382 units in 1999. The large drops in the stocks of housing were mainly a result of housing developers deciding not to build.

The direct impacts of the real estate crisis on property owners were prominent for two reasons. First, the value of property itself had decreased, which adversely affected the wealth of the property owners. Second, various groups were adversely affected by the drop in property prices after the bubble burst. For households, their wealth decreased. The burst of the bubble forced the economy to consume less. For businesses, the drop in property prices forced some credit-constrained firms to sell their property to cover their collateral; for others, it forced owners to shut down production, and some eventually went bankrupt. Housing developers also faced difficulties in financing their unfinished projects and had to terminate them. The over-shooting effect caused by the reduction in prices since the property was sold out turned out to have had much greater impacts on property prices compared with the initial impacts caused by the bubble bursting. ${ }^{2}$

\footnotetext{
${ }^{2}$ Over-shooting effects are varied by different types of real estate. Renaud, Zhang, and Koeberly (1998) investigated commercial buildings in Thailand, such as shop-houses and office buildings, and found that the drop in their prices was more than three times that of residential units.
} 
Figure 1: Housing Units, by Housing Project, Apartment and Condominium, and Self-built Housing (Unit: Numbers of Housing Units)

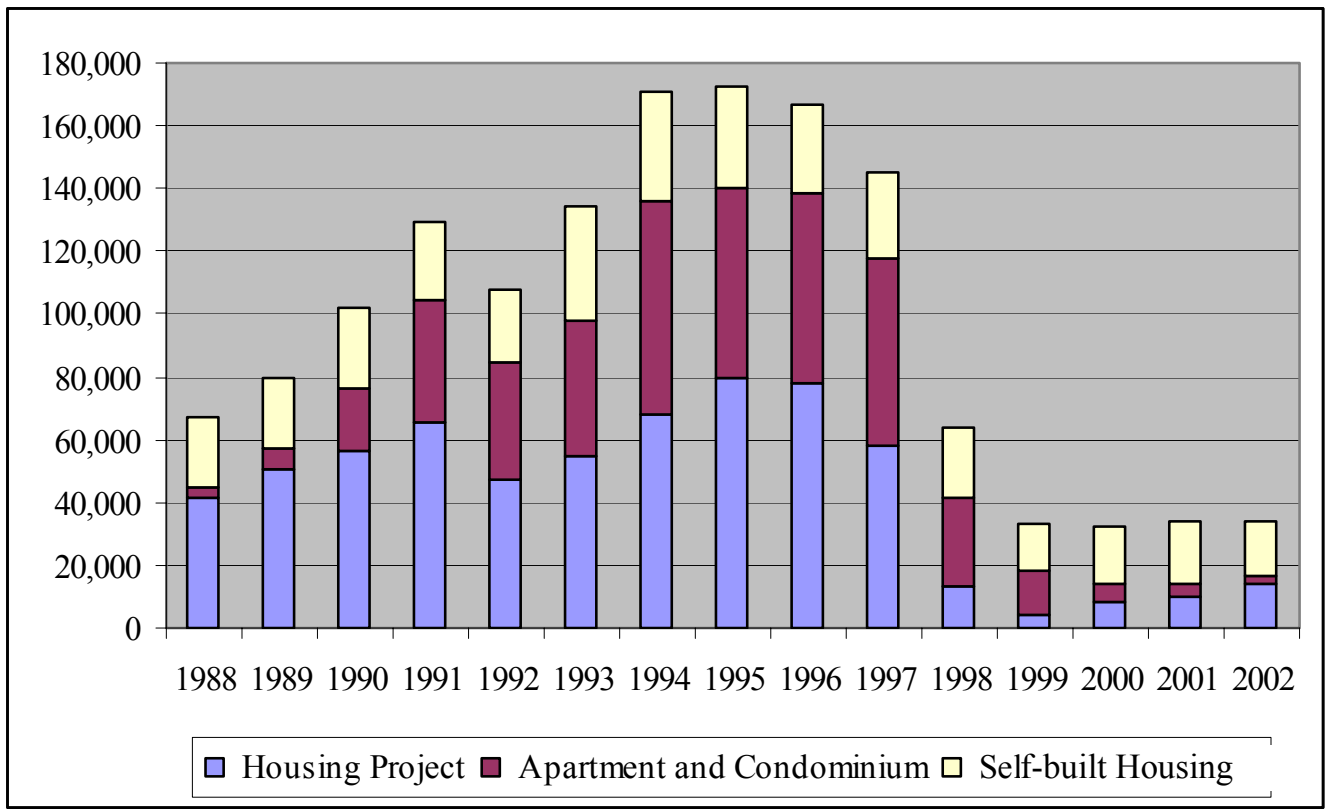

Source: Government Housing Bank; figure constructed by the author

In addition, the real estate crisis led to a costly economic crisis owing to the high vacancy rate and excessive supply of units on the market. Misallocation of resources was the major cause of overvaluation and market distortion. This type of economic cost did not receive much attention, especially with regard to accounting aspects. However, the resource misallocation generated huge losses weighing down the overall economy. 


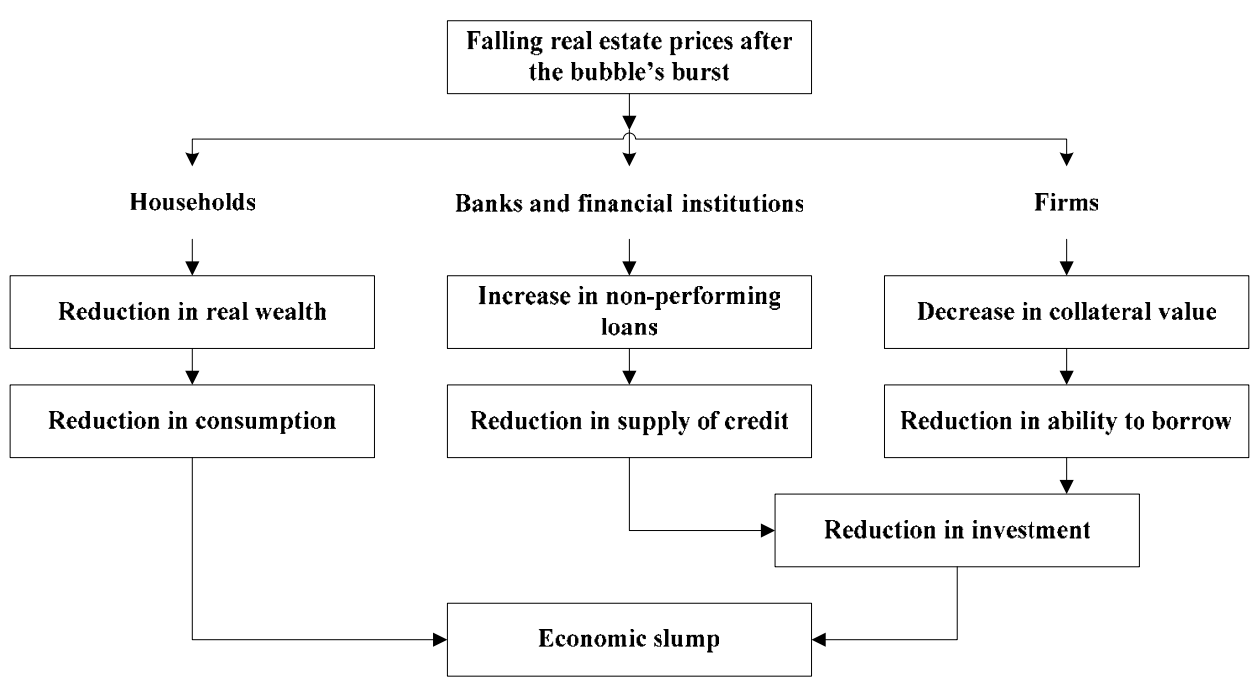

As mentioned previously, the excessive amount of credit stimulated rapid investment in this sector. Besides the supply side, housing demand was also greatly affected by the huge amount of credit extension. Easy assess to the capital market seemed to make people less aware of the need to use loans carefully. The formal pattern of purchasing a house in which to live changed to purchasing a house for investment; typically for speculation. Historical data show that the ratios of financial credit extended to the real estate sector were quite high before the crisis, which consequently led to the speculative behavior of buyers and excessive construction by the sellers.

Furthermore, there were tremendous amounts of foreign direct investment (FDI) inflows when Thailand liberalized its financial sector. Approximately 45 percent of domestic investment came from foreign direct investors and approximately 15 percent of that amount was from borrowers using BIBF procedures. Also, approximately 5 percent and 15 percent of BIBF inflows were allocated respectively to the purchase of construction equipment related directly or indirectly to the real estate market (Renaud, 2000). The greater proportion of housing credit was supplied by commercial banks. At the end of 1997, the amount of credit extended to Thailand's housing sector was as high as 800,000 million baht, or approximately 9 percent of the total banking credit (or approximately 26 percent of credit from finance companies). The amounts of real estate credit peaked at about 20 percent of the total credit from banks. Pre-finance credit was about 5 percent higher than that of post-finance, until the year 2000, when post-finance started to increase while that of pre-finance started to drop. 
Approximately 70.6 percent of the total credit to the real estate sector in 1991 was from commercial banks; however, it dropped significantly to over 53 percent in 2002. As with the finance companies, the share of total credit to this sector had been 8.5 percent in 1991, but dropped to only 0.9 percent in 2002 after 56 finance companies had been suspended in 1998. However, as the second largest provider of credit to this sector, the share of the Government Housing Bank was about 20.5 percent of the total real estate credit in 1991; its share increased to over 39 percent in 2002. That Bank likewise extended its credit to this sector from 0.37 percent in 1991 to about 7 percent in 2002.

\section{Table 1: Real Estate Credit by Financial Institution (Unit: Million Baht)}

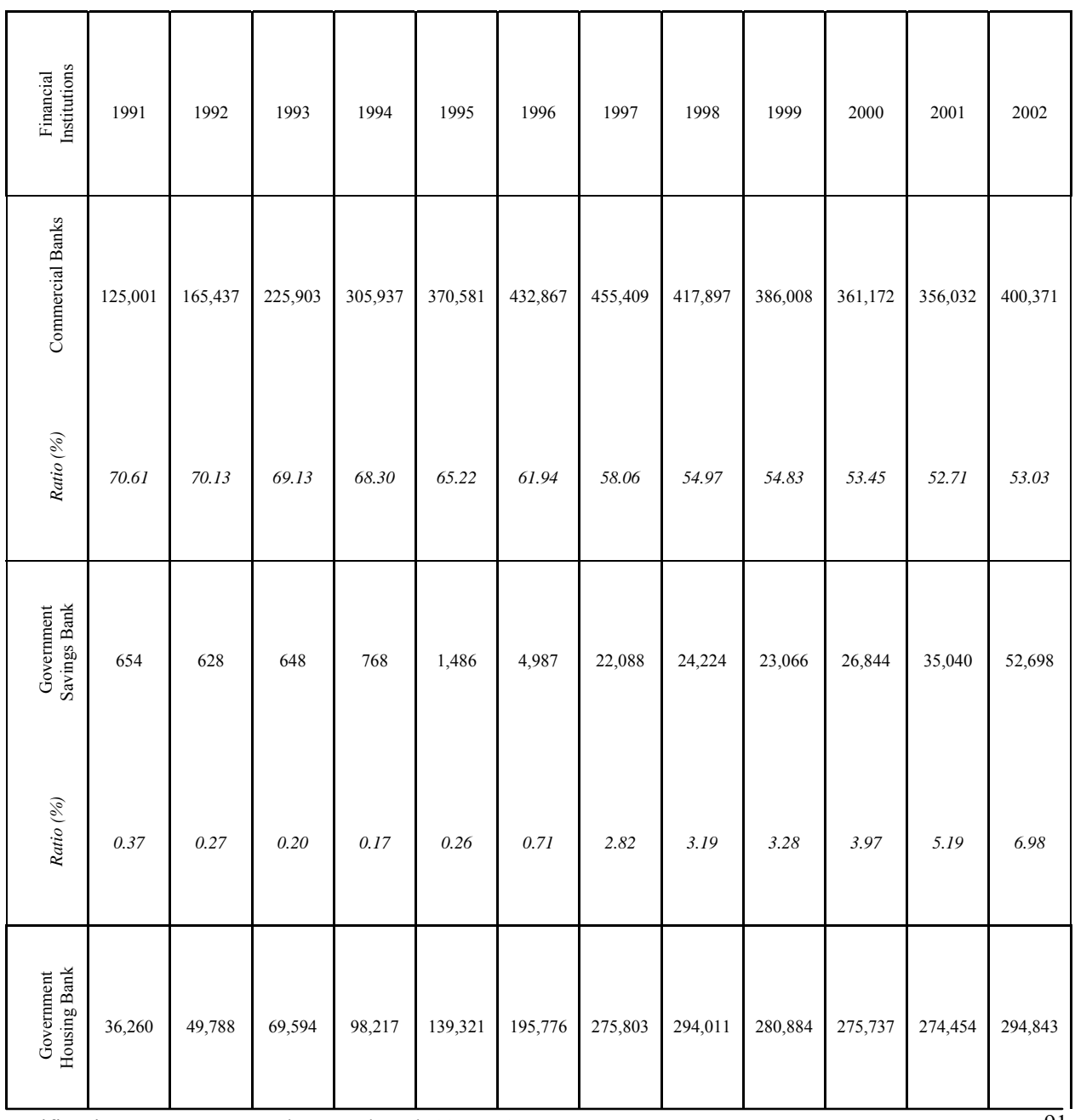

Pacific Rim Property Research Journal, Vol 12, No 1 


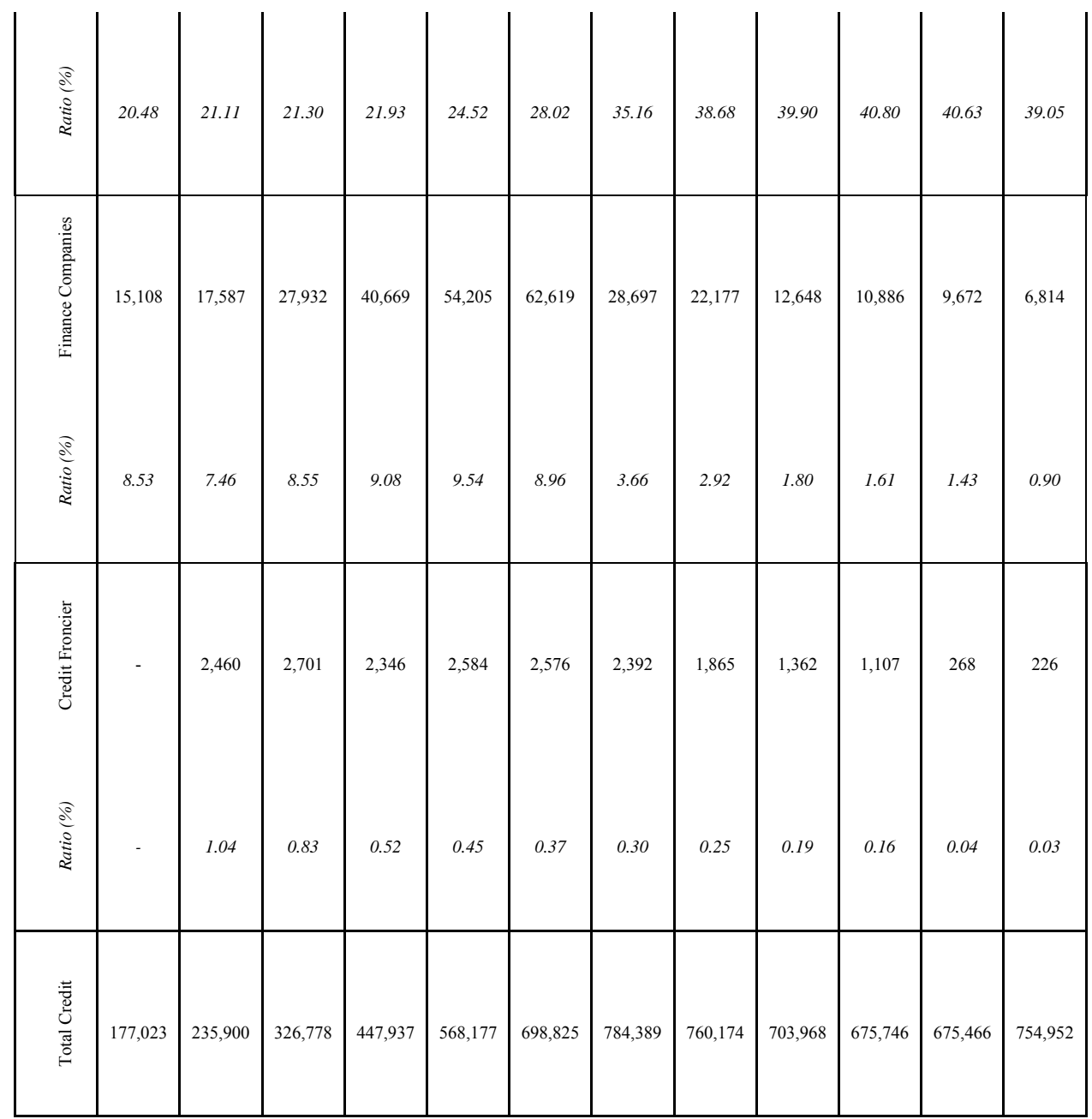

Source: Bank of Thailand.

\section{Real estate market after the crisis}

After the economic slump in 1997, real estate quickly started to recover, along with the economy. A demand for housing was created as well as a supply of housing. In addition, the government developed new regulations as a tool to promote the revival of this sector; for instance, the restructuring of financial institutions, bankruptcy laws, and other policies that could help to stimulate investment. Monetary policy promoted fixed interest rates, which helped buyers to lower the cost of purchasing a house, since the opportunity cost of depositing in banks was as low as 0.75-1.25 percent. 
Financial institutions themselves had to face greater credit competition; they then tried to provide various loan package incentives, such as offering loans for 1-2 years at fixed interest rates. With regard to fiscal policy, transfer fees during the period 2002-2003 were reduced from 3.3 percent to 0.01 percent of the price of a property to stimulate the market.

In addition, to cope with one of the National Housing Authority's policies, a number of developers started to promote the "buy when finished" strategy that helped to encourage customers not to purchase unfinished houses. Housing developers, both big and small, face fierce competition from each other and they regularly assess the number of advertisements for real estate. More creative and modern-style houses appeal to consumers' tastes and preferences. GHB reported that the number of housing projects increased from 13 projects in January 1998 to 227 and 218 projects in November and December 2003 respectively. Approximately 85 percent of those projects were residential and the remaining 15 percent non-residential.

The previous experience of the real estate crisis still makes many people concerned that a similar crisis might happen again. The risk of another crisis should be minimal but more information about it should be released. However, it is not possible to control the risk of future crises. Therefore, a series of effective leading indicators and a system to warn of a future crisis needs to be developed. Section III will focus on an early warning system predicting a real estate crisis.

\section{EARLY WARNING SYSTEM IN THE PROPERTY MARKET}

Bubbles in asset prices are generally hard to measure. Bubbles in the property market are no different. This section explains how bubbles in Thailand's real estate market occurred. As with other assets, bubbles exist when asset prices move above their fundamental values. Therefore, to measure bubbles, the fundamental prices of assets must be calculated. Nevertheless, in practice, the fundamental value of houses is difficult to measure, especially in Thailand, where sufficient real estate data are not widely available. Theoretically, the status of a bubble can be implied when asset prices dramatically increase over a period of time, but decline sharply shortly after the bubble's burst. Changes in asset prices, however, may not imply the existence of a bubble, but can be due to changes in market demand and supply. That means, in terms of the real estate market, sharp price increases alone for property may have few elements of a bubble, especially for durable assets that might require long-term future cash flows (Siegel, 2002; Baker, 2002). Bubbles can be explained by three factors. First, a bubble tends to be deflated if the supply of property on the market becomes more elastic, so that prices would be easier to adjust according to fundamentals (Malpezzi and Wachter, 2002). Second, rational bubbles might be acceptable if the price increases are determined within 
discounted values. Third, bubbles in the real estate market are not necessarily the cause of economic slumps. Therefore, a real estate crisis might exist without a concurrent economic crisis, and visa versa. (Collyns and Senhadji, 2002; Kim, 2000).

This section is aimed at predicting a crisis in the property market. If a real estate crisis is predicted by the model, this implies the status of a bubble today. The prediction of a future crisis therefore can be made by looking backward to see whether or not a bubble currently exists or whether or not property is currently over-priced, i.e., far above its fundamental value. To predict a future crisis, a number of leading indicators are needed to capture all the variables in the market. Leading indicators alone do not capture economic structural changes, such as a tax reduction or subsidy that might stimulate greater investments in the property sector. Nonetheless, leading indicators are required to pass statistical tests to ensure degrees of significance.

The early warning system was initially intended to create a method for anticipating financial and economic crises. There are essentially two alternative methodologies that could serve as the basis for such an early warning system: (1) the signal analysis approach and (2) the probability analysis approach. In this section, both approaches will be analyzed and the complementary outcomes observed between the two models in order to yield the most accurate results.

\section{Signal analysis approach}

The signal analysis approach was initially developed by Kaminsky and Reinhart (1996), and developed further by Kaminsky, Lozondo and Reinhart (1997) to warn of a financial crisis. The signal approach compares the behavior of selected variables in the period preceding a crisis with their behavior in a control group, and identifies those variables. This approach involves monitoring the evolution of a number of important indicators that tend to exhibit unusual behavior in the periods preceding a crisis.

First of all, identification of a crisis situation is a must. For a financial crisis, Kaminsky and Reinhart defined a currency crisis as a situation in which an attack on a currency leads to a sharp depreciation of the value of the currency, a large decline in international reserves, or a combination of those two phenomena. In the case of the real estate crisis in Thailand, three variables can be used to identify the previous crisis as follows:

- "Land prices" started to decline in 1996, which might have reflected the value of the property built on that land.

"Stock prices of firms in the real estate sector" sharply dropped from about 1,045.6 points in January 1996 to less than 20.3 points in August 1998. Thailand's real estate market is dominated mainly by large-size developers which are also listed in the stock market. 
The mean house price in greater Bangkok observed from the GHB database shows that there was a large decline from 2,423,355 baht in January 1996 to 1,104,589 baht in May 1999, after which prices started to revive.

The time horizon for the real estate crisis can be identified from a combination of those three factors mentioned above, occurring during the period January 1996 to May $1999 .^{3}$

A sample period, namely, January 1991 to June 2003 was chosen. A number of potential early warning indicators were selected; the choice of the indicators was dictated by theoretical considerations of a real estate crisis and by the availability of data on a monthly basis. Those indicators were transformed in terms of percentage changes or in terms of ratios in order to identify some seasonality effect. ${ }^{4}$ The indicators should also be able to cope with the following dimensions:

\section{Demand determinants}

- Percentage increase of the consumer price index in the property sector

- Ratio of credit to post-finance and total credit

- Percentage decrease of electricity use in residential units

Supply determinants

- Percentage increase of prices for construction materials

- Percentage decrease of the price of property sector stocks

- Percentage increase in stock of housing

- Ratio of credit to pre-finance and total credit

Other determinants

- Percentage increase in land transactions

- Percentage increase in issuance of land permits

- $\quad$ Market interest rate (MLR)

"Early" in this study is defined according to Kaminsky and Reinhart's definition. As its signaling horizon for a crisis, "early" in this case can thus define the "window" or "signal horizon" as between 1 and 24 months before the beginning of a crisis; that is, the period within which the indicators would be expected to have the ability for anticipating a crisis. Even though the period interval of 12 months is believed to be the most common size for a window, improved predictions can be achieved with a wider window. This paper

\footnotetext{
${ }^{3}$ A housing price index was launched by the Bank of Thailand in November 2004. It could be used as another proxy for a real estate crisis. For example, a real estate crisis might exist when the housing price index drops sharply below a certain point.
}

${ }^{4}$ As suggested by Kaminsky, Linzondo, and Reinhart (1997). 
distinguishes the time horizon between two windows, a 12-month window and a 24month window, to compare the differences in each indicator between both time frames.

\section{Table 2: Signal and Crisis}

\begin{tabular}{|l|c|c|}
\hline \multirow{2}{*}{} & \multicolumn{2}{|c|}{ Window (12 months and 24 months) } \\
\cline { 2 - 3 } & Crisis within 12 months & No crisis within 12 months \\
\hline \multirow{2}{*}{ Signal is issued } & A & B \\
\hline No signal is issued & (Good signal) & (Bad signal or "noise") \\
\hline
\end{tabular}

In order to examine the effectiveness of each indicator, the signal model is evaluated based on the following criteria: the size of Type I and Type II errors, the noise-to-signal ratio, and the probability of a crisis given that a signal was produced within a 12-month (and 24-month) window. In Table 2, A is the number of months in which the indicator produced a good signal; $\mathrm{B}$ is the number of months in which the indicator produced a bad signal; $\mathrm{C}$ is the number of months in which the indicator failed to issue a signal; and $\mathrm{D}$ is the number of months in which the indicator refrained from issuing a signal. Thus, a perfect indicator would produce observations only in A and D.

Therefore, if $H_{0}=$ crisis occurs and $H_{1}=$ no crisis occurs, then the size of a Type I error is the probability of rejecting $H_{0}$ while $H_{0}$ is true (a crisis exists), or the probability of not predicting a crisis, computed as $1-[\mathrm{A} /(\mathrm{A}+\mathrm{C})]$. The size of a Type II error is the probability of not rejecting $H_{0}$ while $H_{0}$ is false, or the probability of signaling a false message (noise), computed as $\mathrm{B} /(\mathrm{B}+\mathrm{D})$. The lower ratio of $[\mathrm{B} /(\mathrm{B}+\mathrm{D})] /[\mathrm{A} /(\mathrm{A}+\mathrm{C})]$, defined a noise-to-signal ratio, indicates a better indicator. Then, the threshold signaling a crisis will be selected when the adjusted noise-to-signal ratio for each variable reaches the minimum point. ${ }^{5}$

Results of the study show that performance to anticipate a crisis varies among indicators. The most effective indicator, observing the minimum noise-to-signal ratio for the 12 month window, is the "interest rate MLR." That means a loan rate exceeding 13.5 percent should signal a crisis. However, this interest rate indicator is less effective for anticipating a 24-month window (with a higher noise-to-signal ratio). Higher interest rates may excessively burden house buyers who have to manage their long-term debt;

\footnotetext{
${ }^{5}$ The 10-25 percentile range may appear arbitrary. The signal model adopted in this sector set the maximum
} 25 percentile as the upper limit, which also implies a one in four probability of issuing a crisis warning when it is not true (Type I error). 
such rates might force buyers to sell their property once they cannot cover losses. A real estate crisis may exist afterward when the value of properties falls as they are sold off. The threshold of the interest rate indicator is the same, 13.5 percent, for the 12-month window and the 24-month window.

Besides the interest rate, other effective indicators are "Percentage increases of the consumer price index in the property sector", "Ratio of credit to post-finance and total credit", and "Percentage decrease of stock prices in the property sector". The percentage increase of the consumer price index exceeding 0.758 percent and 0.539 percent can be used for anticipating a 12-month and a 24-month windows respectively. Increases in the consumer price index should reduce the demand for housing since the CPI in the property sector refers to the cost of living for residents. Thus, house buyers may decide to rent a house instead of attempting to buy one. However, speculative pressure might arise afterwards.

In addition, the percentage drop in stock prices in the property sector is another major indicator signaling a crisis for the 12-month and the 24-month windows, if those prices decrease, respectively, by more than 16.628 percent and 10.643 percent. Stock prices usually reflect the performance of real estate firms, especially of public companies listed on Thailand's stock exchange. A drop in stock prices might infer lower values for the property owned by those firms. In addition, the least effective indicator, observing the maximum noise-to-signal ratio, for the 12-month window is "Percentage increase of housing stock" and for the 24-month window, the "Percentage increase in the price of construction materials."

Some indicators show that their performance is sensitive to the choice of a signaling horizon. Some indicators with the same threshold might be different between windows. Those indicators are "Interest rate MLR", "Ratio of credit to post-finance and total credit", "Percentage increase in land transactions" and "Percentage increase in the stock of housing". Indicators which have the same performance in predicting a crisis, either for the 12-month window or the 24 month-window are "Ratio of credit to pre-finance and total credit" and "Ratio of credit to post-finance and total credit" by observing the same numbers in the noise-to-signal ratio.

A lower noise-to-signal (N-S) ratio implies better indicators. The benefits of the signal model is its ability to anticipate a crisis in a targeted time horizon, which is appropriate for the real estate sector, which usually generates time lags on both sides of market demand and supply. Furthermore, the leading indicators are independent of each other. However, this model still has some weaknesses in determining how important each indicator is in predicting a future crisis. The signal model does not rank or capture the predicted performance of each indicator. Also, the signal model does not provide any 
statistical test of these indicators.

\section{Probability analysis approach}

Probability analysis or probit estimation can eliminate the weaknesses of the first model. Estimations of a probit model provide the probability coefficients (marginal effect) that distinguish the caused degree of each leading indicator of a crisis. In comparing both models, the crisis period is the same as defined in the signal model, which considers the dependent variable as equal to " 1 " during the period between January 1996 and May 1999 and equal to "0" otherwise. The set of indicators used as explanatory variables in the probit estimation are the same as that used for the signal analysis. However, all of the indicators cannot be simultaneously put into the estimation as the presence of multicollinearity among some variables results in large variances and insignificant $t$ statistics. Within a single probit regression with a 6-month and 12-month lag, there are only 4 out of 10 independent variables (indicators) passing the right theoretical prediction and statistical test at the 0.05 significance level:

- $\quad$ Market interest rate MLR (r)

- Percentage decrease of the price of property sector stocks (set)

- Percentage increase of the price of construction materials (con_ind)

- Ratio of credit to post-finance and total credit (post_cre) 
Table 3: Performance of Indicators Based on 12-Month Window

\begin{tabular}{|l|c|c|c|}
\hline \multicolumn{1}{|c|}{ Leading indicators } & $\begin{array}{c}\text { Threshold } \\
(\%)\end{array}$ & N-S ratio & Percentile \\
\hline $\begin{array}{l}\text { Demand determinants } \\
\text { Percentage increase of the consumer price } \\
\text { index in the property sector }\end{array}$ & 0.753 & 0.307 & 19.19 \\
$\begin{array}{l}\text { Ratio of credit to post-finance and total credit } \\
\text { Percentage decrease of electricity use in } \\
\text { residential units }\end{array}$ & 8.748 & 0.237 & 16.16 \\
$\begin{array}{l}\text { Supply determinants } \\
\text { Percentage increase of the price of construction } \\
\text { materials }\end{array}$ & -3.582 & 0.915 & 23.23 \\
$\begin{array}{l}\text { Percentage decrease of the price of property } \\
\text { sector stocks }\end{array}$ & -16.628 & 0.329 & 10.10 \\
Percentage increase in stock of housing & 32.374 & 1.168 & 20.20 \\
Ratio of credit to pre-finance and total credit & 9.952 & 0.651 & 24.24 \\
Other determinants & 13.5 & 0.213 & 21.21 \\
Percentage increase in land transactions & 91.3 & 0.841 & 12.12 \\
Percentage increase in issuance of land permits & & 0.799 & 13.13 \\
Market interest rate (MLR) & & & \\
\hline
\end{tabular}


Table 4: Performance of Indicators Based on 24-Month Window

\begin{tabular}{|c|c|c|c|}
\hline Leading indicators & $\begin{array}{c}\text { Threshold } \\
(\%)\end{array}$ & $\mathrm{N}-\mathrm{S}$ ratio & Percentile \\
\hline \multicolumn{4}{|l|}{ Demand determinants } \\
\hline $\begin{array}{l}\text { Percentage increase of the consumer price } \\
\text { index in the property sector }\end{array}$ & 0.539 & 0.270 & 13.13 \\
\hline Ratio of credit to post-finance and total credit & 8.748 & 0.237 & 16.16 \\
\hline $\begin{array}{l}\text { Percentage decrease of electricity use in } \\
\text { residential units }\end{array}$ & -6.519 & 0.549 & 10.10 \\
\hline \multicolumn{4}{|l|}{ Supply determinants } \\
\hline $\begin{array}{l}\text { Percentage increase of the price of } \\
\text { construction materials }\end{array}$ & 0.725 & 1.929 & 20.20 \\
\hline $\begin{array}{l}\text { Percentage decrease of the price of property } \\
\text { sector stocks }\end{array}$ & -10.643 & 0.684 & 21.21 \\
\hline Percentage increase in stock of housing & 32.647 & 0.865 & 19.19 \\
\hline $\begin{array}{l}\text { Ratio of credit to pre-finance and total credit } \\
\text { Other determinants }\end{array}$ & 9.952 & 0.651 & 24.24 \\
\hline Percentage increase in land transactions & 23.904 & 0.415 & 9.09 \\
\hline $\begin{array}{l}\text { Percentage increase in issuance of land } \\
\text { permits }\end{array}$ & 91.3 & 0.526 & 12.12 \\
\hline Market interest rate (MLR) & 13.5 & 0.531 & 21.21 \\
\hline
\end{tabular}

The above indicators were adopted for the probit model and to calculate the marginal effect that represents the crisis probability of each indicator. The results of the probit estimation show that they have a better predictive power for 12 months than for 6 months, by observing the Z-statistics of each indicator. As with the signal model, the interest rate is found to have had the greatest impact on Thailand's real estate crisis. A 1 percent increase in the interest rate causes an 8.4 percent increase in the probability of a crisis within the next 6 months and an 8.8 percent increase in the probability of a crisis within the next 12 month, or in general an approximately 9 percent increase in the probability of a crisis. The percentage decrease in stock prices is the second-best indicator to predict the probability of a crisis. A 1 percent drop in the price of property sector stock may be expected to cause a 0.3-0.4 percent increase in the probability of a crisis in the next 6-12 months. The price of construction materials shows that a percent increase in those prices might cause a 6.7 percent increase in the probability of a crisis. 
The last indicator, which also has the least ability to predict the probability of a crisis, is the ratio of credit to post-finance to total credit. A 1 percent increase in this indicator might cause only a 1 percent increase in the probability of a crisis in real estate (see Table 5 and Table 6).

Even though these two models seem to be about equal on statistical grounds, the frequencies of actual and predicted outcomes can be calculated. Based on the cut-off probability of 0.5 , the probit model made a reasonably good prediction, especially for a 6 -month prediction by observing the smaller noise-to-signal ratio. ${ }^{6}$ Table 7 shows the number of correct predictions for 40 out of 41 observations for a 6 -month prediction, and 38 out of 41 observations for a 12 -month prediction.

Table 5: Estimation of Probit Model and Marginal Effect: 6-Month Prediction

\begin{tabular}{|c|c|c|c|c|c|c|c|c|}
\hline \multirow{2}{*}{ Indicators } & \multicolumn{5}{|c|}{ Probit estimation } & \multicolumn{4}{c|}{ Marginal effect } \\
\cline { 2 - 9 } & 1 & 2 & 3 & 4 & 1 & 2 & 3 & 4 \\
\hline r(-6) & 0.416 & 0.417 & 0.415 & 1.865 & 0.084 & 0.090 & 0.091 & 0.090 \\
& $(5.70)^{* * *}$ & $(5.65)^{* * *}$ & $(5.68)^{* * *}$ & $(3.22)^{* * *}$ & $(5.70)^{* * *}$ & $(5.65)^{* * *}$ & $(5.68)^{* * *}$ & $(3.22)^{* * *}$ \\
\hline set(-6) & & -0.012 & -0.014 & -0.028 & & -0.003 & -0.003 & -0.001 \\
& & $(-1.59)$ & $(1.77)^{*}$ & $(-1.29)$ & & $(-1.59)$ & $(1.77)^{*}$ & $(-1.29)$ \\
\hline con_ind(-6) & & & 0.303 & 0.132 & & & 0.066 & 0.001 \\
& & & $(1.82)^{*}$ & $(-0.29)$ & & & $(1.82)^{*}$ & $(-0.29)$ \\
\hline post_cre(-6) & & & & 2.244 & & & & 0.011 \\
& & & & $(1.66)^{*}$ & & & & $(1.66)^{*}$ \\
\hline Constant & -5.706 & -5.730 & -5.769 & -4.226 & & & & \\
& $(5.89)^{* * *}$ & $(5.85)^{* * *}$ & $(5.96)^{* * *}$ & $(-0.54)$ & & & & \\
\hline Observations & 154 & 150 & 150 & 116 & 154 & 150 & 150 & 116 \\
\hline
\end{tabular}

Note: $* * *$, and $* * *$ refer respectively to $0.01,0.05$, and 0.1 levels of significance; numbers in parentheses refer to Z-statistics.

\footnotetext{
${ }^{6}$ A cut-off point that is more than 0.5 might generate predicted outcomes that are underestimated (Berg et al., 1999).
} 
Table 6: Estimation of Probit Model and Marginal Effect: 12-Month Prediction

\begin{tabular}{|c|c|c|c|c|c|c|c|c|}
\hline \multirow{2}{*}{ Indicators } & \multicolumn{4}{|c|}{ Probit estimation } & \multicolumn{4}{|c|}{ Marginal effect } \\
\hline & 1 & 2 & 3 & 4 & 1 & 2 & 3 & 4 \\
\hline $\mathrm{r}(-12)$ & $\begin{array}{c}0.356 \\
(5.58) * * *\end{array}$ & $\begin{array}{c}0.355 \\
(5.49)^{* * *}\end{array}$ & $\begin{array}{c}0.366 \\
(5.56)^{* * *}\end{array}$ & $\begin{array}{c}3.372 \\
(2.66)^{* * * *}\end{array}$ & $\begin{array}{c}0.089 \\
(5.58)^{* * *}\end{array}$ & $\begin{array}{c}0.087 \\
(5.49)^{* * * *}\end{array}$ & $\begin{array}{c}0.088 \\
(5.56) * * *\end{array}$ & $\begin{array}{c}0.093 \\
(2.66)^{* * *}\end{array}$ \\
\hline $\operatorname{set}(-12)$ & & $\begin{array}{c}-0.016 \\
(2.08)^{* *}\end{array}$ & $\begin{array}{c}-0.021 \\
(2.42)^{* *}\end{array}$ & $\begin{array}{c}-0.034 \\
(-2.00)^{* *}\end{array}$ & & $\begin{array}{c}-0.004 \\
(2.08)^{* *}\end{array}$ & $\begin{array}{c}-0.005 \\
(2.42)^{* *}\end{array}$ & $\begin{array}{r}-0.001 \\
(2.00)^{* *}\end{array}$ \\
\hline con_ind(-12) & & & $\begin{array}{c}0.439 \\
(2.54)^{* *}\end{array}$ & $\begin{array}{c}1.109 \\
(2.06)^{* *}\end{array}$ & & & $\begin{array}{c}0.105 \\
(2.54)^{* *}\end{array}$ & $\begin{array}{c}0.067 \\
(2.06)^{* *}\end{array}$ \\
\hline post_cre(-12) & & & & $\begin{array}{c}9.08 \\
(2.56)^{* *}\end{array}$ & & & & $\begin{array}{c}0.01 \\
(2.56)^{* *}\end{array}$ \\
\hline Constant & $\begin{array}{c}-4.923 \\
(5.88)^{* * *}\end{array}$ & $\begin{array}{c}-4.941 \\
(5.82)^{* * *}\end{array}$ & $\begin{array}{c}-5.202 \\
(5.96)^{* * *}\end{array}$ & $\begin{array}{c}-5.509 \\
(2.61)^{* * *}\end{array}$ & & & & \\
\hline Observations & 148 & 148 & 148 & 114 & 148 & 148 & 148 & 114 \\
\hline
\end{tabular}

Note: *,*, and *** refer respectively to $0.01,0.05$, and 0.1 levels of significance; numbers in parentheses refer to Z-statistics. 
Table 7: Frequencies of Actual and Predicted Outcomes: $($ Cut-off point $=\mathbf{0 . 5})$

\begin{tabular}{|c|c|c|c|}
\hline \multicolumn{4}{|c|}{ 6-month prediction } \\
\hline \multirow{2}{*}{ Predicted } & \multicolumn{2}{|c|}{ Actual } & \multirow{2}{*}{ Total } \\
\hline & Crisis (1) & Non-crisis $(0)$ & \\
\hline Crisis (1) & 40 & 5 & 45 \\
\hline Non-crisis $(0)$ & 1 & 70 & 71 \\
\hline Total & 41 & 75 & 116 \\
\hline \multicolumn{4}{|c|}{$\begin{array}{c}\text { Proportion of correct predictions }=0.976 \\
\text { Noise-to-signal ratio }=0.0683 \\
\end{array}$} \\
\hline \multicolumn{4}{|c|}{ 12- month prediction } \\
\hline \multirow{2}{*}{ Predicted } & \multicolumn{2}{|c|}{ Actual } & \multirow{2}{*}{ Total } \\
\hline & Crisis (1) & Non-crisis $(0)$ & \\
\hline Crisis (1) & 38 & 1 & 39 \\
\hline Non-crisis $(0)$ & 3 & 72 & 75 \\
\hline Total & 41 & 73 & 116 \\
\hline \multicolumn{4}{|c|}{$\begin{array}{c}\text { Proportion of correct predictions }=0.927 \\
\text { Noise-to-signal ratio }=0.0148\end{array}$} \\
\hline
\end{tabular}

Both the signal analysis and probability models eliminate the weak points of each other, and thus encourage better predictions. Two indicators reflect a significant effect vis-a-vis the real estate crisis: the ratio of post-finance to total credit, and the percentage increase in the price of construction materials. The ratio of post-finance to total credit increased from 8.2 percent at the end of 2002 to 9.2 percent at the end of 2003, exceeding the threshold (8.748). The price of construction materials started to increase by about 2-3 percent each month from the beginning of 2004, also exceeding the threshold level. Recent increases in construction material prices have been caused mainly by sharp increases in the price of steel.

If observed, the interest rate, the most important and the strongest indicator, is far below the threshold level. Also, commercial banks might currently be playing with the 
competitive atmosphere by offering fixed loan rates, say for 1-3 years, to house buyers who borrow long-term from banks. This strategy has produced a very successful result for house buyers accepting this type of method for paying debt. Therefore, both models are able to predict that a real estate crisis in Thailand should not occur in the next 1-2 years. Time horizons beyond two years however are beyond the ability of the models to predict. $^{7}$

Despite yielding reasonably good predictions, both approaches rely on past information and cannot cover all aspects of crisis prediction. For example, models do not treat the pressure from interest rate increases that might occur in the future. Any other new kinds of shock might occur without warning. Restructuring of the financial system, proper monitoring, new urban planning and providing sufficient information might change the overall structure of the economy and lead to structural changes that may cause a crisis. Expanding estimations in the form of cross-country study or panel data might generate better outcomes.

\section{CONCLUSION}

This paper first analyzes the causes, effects and consequences of past speculative bubbles and the real estate crisis in Thailand. Excessive credit from financial institutions is considered one of the major causes of speculative behaviors. Studying how Thailand's real estate crisis affected the economic slump in 1997 is worth explaining in this section. Next, an early warning system is created to predict future crises in the property market by adopting two methodological approaches: signal analysis and probability analysis. The system shows that there are two leading indicators: "ratio of post-finance to bank loans" and "percentage increase in the price of construction materials" which recently exceeded the threshold level, thus signaling a potential future crisis. Nevertheless, the interest rate, which the models unveil as the most significant indicator with the strongest impacts on a crisis, is still far lower than the threshold level. In addition, to cope with more competitive pressures, a number of Thai financial institutions are offering competitive incentives such as fixed loan rates, for 1-3 years, to house buyers. For these reasons, the probability of a real estate crisis occurring in Thailand will remain very low for the next 1-2 years (2005-2007). Nevertheless, models do not treat pressures caused by other incidents, such as restructuring the financial system, proper monitoring and new urban planning, which might change the structure of the economy. Therefore, the ability

\footnotetext{
${ }^{7}$ Even though the model prediction of no real estate crisis occurring in Thailand during 2005-2007, due to the hike of oil price, the current trend of higher interest rate in Thailand during 2006 should come into the consideration of both housing developers and house buyers. Those who borrow long-term from banks must face more burdens.
} 
of the early warning system created by using past records might not be able to fully secure the market.

\section{REFERENCES}

Baker, Dean. 2002. "The Run-Up in Home Prices: Is It Real or Is It Another Bubble?," Center for Economic Policy Research.

Berg, A, E. Borensztein, G. M. Milesi-Ferretti, and C. Pattillo. 1999. Anticipating Balance of Payment Crises: The Role of Early Warning Systems, Occasional Paper, No.186, International Monetary Fund, Washington, D.C.

Collyns, Charles and Abdelhak Senhadji. 2002. "Lending Booms, Real Estate Bubbles, and the Asian Crisis." IMF Working Paper No. WP/02/20.

Corsetti, Giancorlo, Paolo Pesenti, and Nouriel Roubini. 1998. "What Caused the Asian Currency and Financial Crisis? Part I: A Macroeconomic Overview." Mimeo, 1-39.

Edison, Hali, Luangaram, Pongsak, and Marcus Miller. 2000. "Asset Bubbles, Leverage and Lifeboats: Elements of the East Asian Crisis.” Economic Journal, Vol. 110, 235-255.

Kaminsky, Graciela, and Carmen M. Reinhart. 1996. "The Twin Crisis: The Causes of Banking and Balance-of-Payment Problems." International Finance Discussion Paper, No. 544 (March), Board of Governors of the Federal Reserve System, Washington, D.C.

Kaminsky, Graciela, Saul Lizondo, and Carmen M. Reinhart. 1997. "Leading Indicators of Currency Crises." IMF Working Paper, WP/97/79.

Kim, Kyung-Hwan. 2000. "Korea: Could a Real Estate Price Bubble Have Caused the Economic Crisis." In Koichi Mera and Bertrand Renaud, editors, Asia's Financial Crisis and the Role of Real Estate. New York: M.E. Sharpe, Armonk.

Luangaram, Pongsak, and Markus Miller. 2004. "Asset Price Bubble and Financial Forbearance: The Role of Margin Requirement.” Working paper, University of Warwick. Mimeo.

Melpezzi, Stephen, and Susan M. Wachter. 2002. "The Role of Speculation in Real Estate Cycles." Paper prepared for the July 2002 joint meeting of the American Real Estate and Urban Economics Association, Seoul, South Korea. Mimeo.

Renaud, Bertrand. 2000. "How Real Estate Contributed to the Thailand Financial Crisis." In Koichi Mera and Bertrand Renaud, editors, Asia's Financial Crisis and the Role of 
Real Estate. New York: M.E. Sharpe, Armonk.

Renaud, Bertrand, Ming Zhang, and Stefan Koeberle. 1998. "How the Real Estate Boom Undid Financial Institutions: What Can Be Done Now?" Proceedings of the National Economic and Social Development Board-World Bank Conference on Thailand's Dynamic Recovery and Competitiveness, May 21-24, Bangkok.

Siegel, Jeremy, J. 2002. "What is an Asset Price Bubble? An Operational Definition." Wharton School, University of Pennsylvania, mimeo. 